\title{
The Characteristics of Cytochrome C Oxidase Gene Subunit I in Wild Silkmoth Cricula trifenestrata Helfer and Its Evaluation for Species Marker
}

\author{
Suriana $^{a}{ }^{*}$, D. D. Solihin ${ }^{\mathrm{b}}$, R. R. Noor ${ }^{\sharp}$, \& A. M. Thohari ${ }^{\mathrm{d}}$ \\ ${ }^{\text {a }}$ Department of Biology, Faculty of Science, Haluoleo University \\ Jln. HEA Mokodompit Kampus Hijau Bumi Thidarma Anduonohu Kendari, Indonesia \\ bDepartment of Biology, Faculty of Science, Bogor Agricultural University \\ 'Department of Animal Production and Technology, Faculty of Animal Science, Bogor Agricultural University \\ \#Jln. Agatis Kampus IPB Darmaga, Bogor 16680, Indonesia \\ ${ }^{\mathrm{d}}$ Department of Conservation, Faculty of Forestry, Bogor Agricultural University \\ Jln. Lingkar Akademik Darmaga, Bogor 16680, Indonesia \\ (Received 21-02-2012; accepted 23-04-2012)
}

\begin{abstract}
ABSTRAK
Penelitian bertujuan untuk mengkarakterisasi dan mendeteksi situs diagnostik dari parsial gen sitokrom C oksidase sub unit I (COI) ulat sutera liar Cricula trifenestrata, dan mengevaluasi gen tersebut sebagai penanda spesies. Sebanyak 15 larva $C$. tifenestrata dikoleksi dari Kabupaten Bogor, Purwakarta, dan Bantul. DNA genom diekstrak dari kelenjar sutera larva, kemudian diperbanyak dengan metode PCR dan disekuensi. Hasil sekuensi dikarakterisasi runutan nukleotida dan diprediksi kandungan asam aminonya. Hasilnya menunjukkan bahwa 595 runutan nukleotida pada ujung $5^{\prime}$ gen COI C. tifenestrata bersifat kekal pada level spesies, tetapi beragam pada level family. Nukleotida didominasi oleh basa timin dan adenin $( \pm 70 \%)$. Terdapat 25 situs diagnostik bagi C. tifenestrata dan 4 situk diagnostik pada level genus. Seratus delapan puluh sembilan (189) asam amino yang disejajarkan, menunjukkan satu persen variasi antar spesies. Asam amino ke-107 (valin) dan asam amino ke-138 (treonin) merupakan asam amino diagnostik bagi C. tifenestrata. Berdasarkan runutan nukleotida dan asam aminonya, filogeni kekerabatan menunjukkan bahwa $C$. tifenestrata terdapat pada nodus yang sama dengan spesies Antheraea, sehingga family Saturniidae bersifat monofiletik.
\end{abstract}

Kata kunci: ulat sutera liar, C. trifenestrata, sitokrom oksidase sub unit I, nukleotida diagnostik, asam amino diagnostik

\section{ABSTRACT}

The study was conducted to assess the characteristics of partial gene of cytochrome $\mathrm{C}$ oxidase subunit I (COI) of wild silkmoth Cricula trifenestrata, and to detect the diagnostic sites from these gene for evaluation as species marker. A total of fifteen larvae of $C$. tifenestrata were collected from Bogor, Purwakarta, and Bantul Regencies. Genomic DNA was extracted from silk gland of individual larvae, then amplified by PCR method and sequenced. DNA sequencing was done to characterize their nucleotide and amino acid contents. The results showed that 595 nucleotides at the 5 'end of COI gene of $C$. tifenestrata was conserved at the species level, but varies at the family level. Nucleotide dominated by thymine and adenine bases $( \pm 70 \%)$. There were 25 diagnostic sites for $C$. tifenestrata, and four diagnostic sites for genus level. One hundred eigthty nine (189) amino acids were alignment, and only one percent of the genes was varied among species. The $107^{\text {th }}$ amino acid (valine) and $138^{\text {th }}$ (threonine) were diagnostics amino acid for $C$. tifenestrata. Based on nucleotides and amino acids sequences, the phylogeny showed that $C$. tifenestrata lied on the same nodes with Antheraea, so the Saturniidae family is monophyletic.

Key words: wild silk moth, C. trifenestrata, cytohrome C oxidase subunit I, nucleotide diagnostic, amino acid diagnostic

\footnotetext{
* Corresponding author:

E-mail: deasuriana@yahoo.co.id
} 


\section{INTRODUCTION}

The golden silkmoth, is one local name for Cricula trifenestrata Helfer; and the member of the Saturniidae family (superfamily Bombycoidea), in which include the giant silkmoths, royal moths, and emperor moths. This family is the largest and most spectacular of the Lepidoptera, with an estimated number of 1,300-1,500 species (Tuskes et al., 1996). The Saturniidae family, for example domesticated silkmoth (Bombyx mori), has a great attraction among the silkmoth family (Bombycidae). In addition, some species of the family are wild silkmoths which can also produce silk. C. trifenestrata was conspicuous by having perforated cocoon, which golden yellow color. Male wing span is $56-78 \mathrm{~mm}$, while female wing span is 75-81 mm (Kakati \& Chutia, 2009). This species is distributed in throughout Filipine, India and Indonesia, and there are many endemic species in Indonesia Island such as in Sumatera, Java, and Sulawesi (Nassig et al., 2006). Study based on biology, ecology and genetics aspects of this insect is therefore necessary. As $C$. trifenestrata is a closely related to species of Antheraea and B. mori, the mitochondrial genome information of the species may provide fundamental information for future phylogenetic analyses and evolutionary biology.

Recent investigations have suggested mitochondrial genome (mtDNA) as a tool for studying the taxonomy, and evolution of animal populations. The cytochrome oxidase subunit I (COI) gene is a part of mtDNA. This gene was chosen because of its central role in metabolism and its presence is in almost all eukaryotes. Additionally, the size and structure of COI gene has been well conserved in the animal groups analysed so far, a feature which makes it especially suitable for evolutionary studies (Lunt et al., 1996). The COI, however, is one of the most conserved mitochondrial protein-coding genes in animals (Mueller, 2006), and thus displays a better phylogenetic signal (Wilson, 2010). COI as a barcode marker has been used very successfully in many animal taxa, for examples: differentiated among family in Lepidoptera (Wilson, 2010), beetles (Funk et al., 1995), some insect pests (Toda \& Murai, 2006) Mermerodes hamona moth (Hulrc et al., 2007), mosquito (Cywinska et al., 2006), and Thrips tabaci (Karimi et al., 2010).

Several cytochrome oxidase genes have been sequenced and characterized in silkmoth, i.e: Bombyx mori (Li et al., 2005; Arunkumar et al., 2006). Similar studies in wild silkmoth (Saturniidae family) have been done, especially in some species of Antheraea (Arunkumar et al., 2006; Mahendran et al., 2006), but has not been done in the Saturniidae of Indonesia. Study of C. trifenestrata is still minimally performed in the existing of taxonomy based on morphology. Molecular data is an appropriate alternative to complement the morphological data. Beside as the basic information, molecular data can be used as the basic study for selection, the business development of the utilization of wild silkworm, especially $C$. trifenestrata. Up to present, there are only limited data on the molecular characteristics of the partial coding genes in insect silk (Suriana et al., 2011). It is therefore, important to do more advanced research.
This study aimed to: (1) characterize, (2) detect the site of nucleotide and amino acid diagnostics COI gene for C. trifenestrata, and (3) examine the relationship of kinship among the silk-producing insects based on nucleotide and amino acid COI sequences. The results were described based on genetics backgrounds, so it would be the first molecular database for C. trifenestrata wich can be used as species marker.

\section{MATERIALS AND METHODS}

A total of fifteen larvae of the wild silkmoth $C$. trifenestrata were collected from Bogor and Purwakarta Regencies of West Java, and Bantul Regency of Central Java, Indonesia.

\section{Genomic DNA Isolation}

Genomic DNA was prepared from a pair of silk glands of final instar larvae of C. trifenestrata using a standard technique (Sambrook et al., 1989) that has been adjusted.

\section{Electrophoresis}

Genomic DNA was migrated on $1.2 \%$ agarose gel in 1xTBE solution using tools of submarine electrophoresis (Hoefer, USA). Ethidium bromide $(0.5 \mathrm{ug} / \mathrm{ml})$ was used for staining of the gel, and visualized under UV transiluminator $(\lambda=300 \mathrm{~nm})$.

\section{COI Gene Amplification and Sequencing}

A region of COI gene derived from $C$. trifenestrata was amplified by using a Thermal Cycler Eppendorf Type 5332 machine. The primer used were forward 5'TGATCA-AATTTATAATAC-3' and reverse 5'-GTAAAAT TAAAA-TATAAAC-3' (Mahendran et al., 2006).

The program of PCR amplification was as follows 1 min at $94^{\circ} \mathrm{C}$, followed by 35 cycles of $30 \mathrm{sec}$ at $94{ }^{\circ} \mathrm{C}, 45$ sec at $40^{\circ} \mathrm{C}$, and $1 \mathrm{~min}$ at $72^{\circ} \mathrm{C}$, with a subsequent $5 \mathrm{~min}$ for final extension at $72{ }^{\circ} \mathrm{C}$. Reagent components were $2 \mu \mathrm{l}$ DNA template, $1.5 \mu \mathrm{l}$ of each 10 picomol primer, $12.5 \mu \mathrm{l}$ of buffer ready to mix, $0.5 \mathrm{ul} \mathrm{MgCl} 250 \mathrm{mM}$, and added double destiled $\mathrm{H}_{2} \mathrm{O}$ up to $25 \mu \mathrm{l}$ total volume. DNA sequencing was done by using Applied Biosystem 3730 XL DNA Analyzer.

\section{Phylogenetic Construction}

Characterization of $C$. trifenestrata COI gene was carried out using MEGA 4. Software (Tamura et al., 2007); sequence was alignmented to determine the position of these gene at COI gene data from GenBank. COI data for same species and genus were not available on the GenBank, therefore we used COI data for family level, i.e: six species of Antheraea (Saturniidae): A. pernyi (HQ264055), A. mylitta (AY 605 255) and A. yamamai (AF029067). A. assama (AY605249), A. proiily (AY960274), and A. roilei (AY960274). Bombyx mori (AF027953) sequence was used as outgroup. The final step phylogenetics tree was constructed by using the Neighborn 
Joining method with 1000x boostrapped, and Kimura 2-parameter model (Nei \& Kumar, 2003).

\section{RESULTS AND DISCUSSION}

\section{General COI Partial Gene Features of C. trifenestrata}

Amplification results of COI gene derived from $C$. trifenestrata was at long sequence of 595-602 base pairs (bp). The nucleotide sequence was aligned parallel to the nucleotide positions 138-740 in the COI gene sequences from GenBank data. This position was an area proposed as the animal barcode region (Hulrc et al., 2007). Sequence data are characterized along of $595 \mathrm{bp}$, encoding 198 amino acids. The position of these amino acids was aligned with $48^{\text {th }}$ up to $245^{\text {th }}$ of the amino acid $A$. pernyi as a reference. These sequences have been submitted to GenBank with the accession number of JF264728.

\section{Nucleotide Composition and Diagnostics Sites}

Compared base $\mathrm{N}$ composition of each species is presented in Table 1 . The base $\mathrm{N}$ composition of each species showed varies. There are trend that timine was higest base $\mathrm{N}$, while guanine was lowest base $\mathrm{N}$ percentage for each species.

Based on Table 1, this base $\mathrm{N}$ composition was consisted of $38 \%-41.8 \%$ thymine $(\mathrm{T}), 27.6 \%-32.9 \%$ adenine (A), $15.8 \%-18.5 \%$ cytosine $(\mathrm{C})$, and $13.3 \%-14.6 \%$ guanine (G). The dominance of $\mathrm{T}$ and $\mathrm{A}$ bases in each species were mainly found in the third codon, as has also been observed in other insect: B. mori (Arunkumar et al., 2006), A. pernyi (Liu et al., 2008), A. yamamai (Kim et al., 2009), and Hyphantria cunea (Liao et al., 2010), Eriogyna pyretorum (Jiang et al., 2009). A possible explanation for this differences that the base constraints on $\mathrm{T}+\mathrm{A}$ content in this first and second codon positions are less relaxed than those in the third codon position is due to degenerated genetic code (Funk et al., 1995; Liu et al., 2008).

The alignments results of $595 \mathrm{bp}$ COI gene among C. trifenestrata populations showed that genes were highly conserve the species level, but diverse with other silkmoth species, both in Saturniidae (the same family), and Bombycidae (different family). There were 454/595 (76.3\%) conserved nucleotides, and 141/595 (23.7\%) variable nucleotides. The variable nucleotides, consisted

Table 1. Percentage base $\mathrm{N}$ composition of COI gene C. trifenestrata and GenBank data

\begin{tabular}{lcccc}
\hline Species & $\mathrm{T}$ & $\mathrm{C}$ & $\mathrm{A}$ & $\mathrm{G}$ \\
\hline C. trifenestrata & 40.7 & 18.5 & 27.5 & 13.3 \\
A. pernyii & 40.4 & 17.3 & 29.4 & 12.9 \\
A. yamamai & 41.8 & 15.9 & 28.9 & 13.4 \\
A. mylitta & 41.3 & 16.5 & 28.9 & 13.3 \\
A. assama & 40.2 & 17.1 & 29.2 & 13.4 \\
A. proylei & 40.7 & 17.0 & 29.2 & 13.1 \\
A. roylii & 41.0 & 16.5 & 29.2 & 13.3 \\
B. mori & 38.0 & 15.8 & 32.9 & 13.3 \\
\hline
\end{tabular}

of 99/595 (16.6\%) parsimony informative nucleotides and 42/595 (7\%) singleton nucleotides (Table 2). Similar results were observed in other insect, for examples: a lower $(1 \%)$ of intra-species nucleotide diversity based on the COI gene was also found by Li et al. (2009); Weagener et al. (2006); Cywinska et al. (2006). Nevertheless, at the level of genus, COI was successed to separate the beetle genus Ophraella and showed the diversity among species up to $24 \%$ (Funk et al. 1995), insect pests Thrips tabaci tobacco up to $4.8 \%$ (Toda \& Murai, 2007), and mosquitoes (Culicidae) 0.2\%-17.2\% (Cywinska et al., 2006).

Composition of the COI nuleotida $C$. trifenestrata is relatively consistent with the nucleotide composition of the COI sequences found in other insects, particularly Lepidoptera. There is a tendency of dominance of thymine and adenine bases that caused by the use of bases such as triplet codons. The applicability of the triplet codons is associated with the availability of the corresponding tRNA and also the rate of gene expression. Addition of nucleotide composition related to the rate of base substitution. Transition substitution was larger than transversion substitution. This is consistent with the results of this study, and as found by Toda \& Murai (2006) wich $A \leftrightarrow G$ substitutions, was greater than the $\mathrm{C} \leftrightarrow \mathrm{T}$, synonymous mutations was larger than nonsynonymous mutations. Due to the substitution it was found 5 diagnostic nucleotide sites that can be utilized as species marker for $C$. trifenestrata.

Nucleotide differences among species ranged from 14 up to 92 were presented in Table 3. From those nucleotide differences, there were 25 sites of diagnostic for the $C$. trifenestrata species, and four diagnostics sites for genus of silkmoth, i.e $30^{\text {th }}, 174^{\text {th }}, 325^{\text {th }}$, and $396^{\text {th }}$ sites respectively. Diagnostic sites among species, genus and family of silkmoth based on 595 bp COI gene is presented in Table 4. The diagnostic site was used as a molecular marker species, family and other taxa because it showed diverse parameters. This study was shown many diagnostic sites for $C$. trifenestrata. However, the data are not available from GenBank for other Cricula species, so the comparison performed at the family level is rougher.

\section{Amino Acid Composition and Diagnostics Sites}

The COI gene of C.trifenestrata has 595 bp long, translated into 189 amino acids which are aligned with A. pernyi amino acid as a reference at the position of $48^{\text {th }}$ up to $245^{\text {th }}$. The COI amino acids of C. trifenestrata, were conserved at the species level. Amino acid composition was dominated by leucine and isoleucine (up to $25 \%$ from 189 amino acid sequence), whereas other amino acids were present in smaller amounts (Table 5).

Contrary to the nucleotide, amino acid alignment results of $C$. trifenestrata with amino acid in the GenBank data, showed a little variability. There were 178/198 (90\%) that conserved amino acids, the remainder was $20 / 198(10 \%)$ variable amino acid. The varies amino acid among species and their sites is presented in Table 6 .

Table 6 showed that the valine $\left(107^{\text {th }}\right.$ site) and threonine $\left(138^{\text {th }}\right.$ site) are the diagnostic amino acid on $C$. trifenestrata. The diagnostics amino acid for A. yamamai 
Table 2. The alignments result of $595 \mathrm{bp}$ COI gene C. trifenestrata and with species from GenBank data

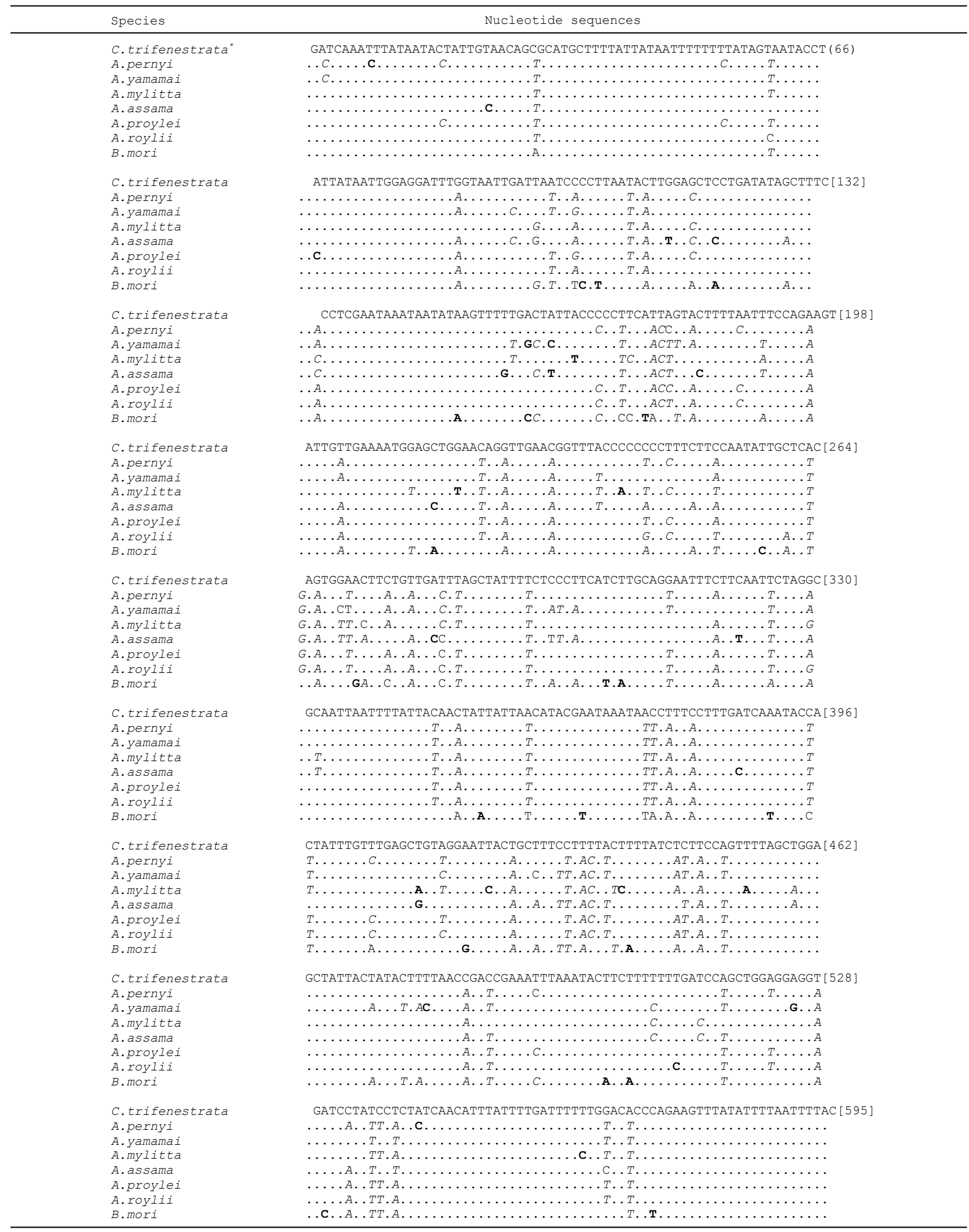

Note: *There were 15 sequences, only one showed here because which were monomorphic. Numbers in parentheses indicate sites number. (.) indicate conserved nucleotides (identical nucleotides) among species. Italic letters indicate parsimony informative nucleotides, and bolled letters indicate singleton nucleotides for each species. 
Table 3. The difference of number and percentage of COI nucleotide on C. trifenestrata compared with GenBank data

\begin{tabular}{|c|c|c|c|c|c|c|c|c|}
\hline Species & 1 & 2 & 3 & 4 & 5 & 6 & 7 & 8 \\
\hline 1 & - & & & & & & & \\
\hline 2 & $74(12,4)$ & & & & & & & \\
\hline 3 & $79(13,3)$ & $39(6,6)$ & & & & & & \\
\hline 4 & $73(12,3)$ & $47(7,9)$ & $56(9,4)$ & & & & & \\
\hline 5 & $82(13,8)$ & $55(9,2)$ & $46(7,7)$ & $55(9,2)$ & & & & \\
\hline 6 & $72(12,1)$ & $55(9,2)$ & $38(6,4)$ & $46(7,7)$ & $54(9,0)$ & & & \\
\hline 7 & $69(12,0)$ & $15(2,5)$ & $37(6,2)$ & $44(7,3)$ & $53(8,9)$ & $14(2,3)$ & & \\
\hline 8 & $92(15,3)$ & $69(11,6)$ & $69(11,6)$ & $83(14,0)$ & $80(13,4)$ & $67(11,3)$ & $66(11,0)$ & - \\
\hline
\end{tabular}

Note: $1=$ C. trifenestrata, $2=A$. pernyi, $3=$ A. yamamai, $4: 5=A$. assama, $6=A$. proylei, $7=A$. roylii, $8=B$. mori. Numbers in parentheses indicate percentage of nucleotides difference.

Table 4. Diagnostic sites among species, genus and family of silkmoth based on $595 \mathrm{bp}$ COI gene

\begin{tabular}{|c|c|c|c|c|c|}
\hline \multirow[b]{2}{*}{ Species } & \multicolumn{5}{|c|}{ Nucloetide sites } \\
\hline & $\begin{array}{r}1111 \\
30177 \\
02148\end{array}$ & $\begin{array}{l}12222 \\
92356 \\
85127\end{array}$ & $\begin{array}{l}23333 \\
92356 \\
45010\end{array}$ & $\begin{array}{l}33333 \\
77789 \\
56816\end{array}$ & $\begin{array}{l}44555 \\
48234 \\
73870\end{array}$ \\
\hline C. trifenestrata & $\underline{\text { GCTAG }}$ & TTGCT & CECCC & ССТCA & ТСТСС \\
\hline A. mylitta & TAATA & AAAAA & TIAAT & TTAAT & AAATA \\
\hline A. yamamai & TGATA & AAAAA & TTAAT & TTAAT & AAATT \\
\hline A. pernyi & $\underline{T A A T A}$ & AAAAA & TTGAT & TTAAT & AAATA \\
\hline A. proylei & TAATA & AAAAA & TIAAT & TTAAT & AAATT \\
\hline A. assama & TGATA & AAAAA & TTAAT & TTAAT & AAATA \\
\hline A. proiily & $\underline{T A A T A}$ & AAAAA & TTGAT & TTAAT & AAATA \\
\hline B. mori & $\underline{\text { ATAC}} \underline{\mathrm{C}}$ & AAAAA & TㅁAAT & TTAA드 & AAATA \\
\hline
\end{tabular}

Note: $\mathrm{G}=$ guanine, $\mathrm{A}=$ adenine, $\mathrm{C}=$ cytosine, $\mathrm{T}=$ timine. Arrow shows the direction readings. Bolled letters indicate diagnostic sites for $\mathrm{C}$. trifenestrata and underlined letters indicate diagnostic sites for each genus.

Table 5. Percentage 189 amino acid sequence on C. trifenestrata compared with GenBank data

\begin{tabular}{lccccccccccccccccccccccc}
\hline \multicolumn{1}{c}{ Species } & Ala & Cys & Asp & Glu & Phe & Gly & His & Ile* & Lys & Leu* & Met & Asn & Pro & Gln & Arg & Ser & Trh & Val & Trp & Tyr \\
\hline $\begin{array}{l}\text { C. } \text { tri- } \\
\text { fenestrata }\end{array}$ & 7.07 & 0.00 & 3.53 & 1.01 & 8.08 & 8.08 & 2.53 & 11.11 & 0.00 & 14.14 & 6.06 & 6.06 & 6.57 & 1.52 & 1.52 & 7.58 & 5.56 & 5.05 & 2.53 & 2.00 \\
A. pernyi & 7.07 & 0.00 & 3.53 & 1.01 & 8.08 & 8.59 & 2.53 & 11.11 & 0.00 & 14.14 & 6.06 & 6.06 & 6.57 & 1.52 & 1.52 & 7.58 & 5.56 & 4.52 & 2.53 & 2.02 \\
A. yama- & 7.07 & 0.00 & 3.05 & 1.02 & 8.12 & 8.63 & 2.54 & 11.17 & 0.00 & 14.21 & 6.09 & 6.60 & 6.60 & 1.61 & 1.52 & 7.58 & 5.56 & 4.06 & 2.54 & 2.03 \\
mai & & & & & & & & & & & & & & & & & & & & & & & \\
A. mylitta & 7.07 & 0.00 & 3.54 & 1.01 & 8.08 & 8.59 & 2.53 & 10.61 & 0.00 & 13.64 & 6.06 & 6.06 & 6.57 & 1.52 & 1.52 & 8.04 & 5.56 & 5.05 & 2.53 & 2.02 \\
A. assama & 7.07 & 0.00 & 3.54 & 1.01 & 8.08 & 8.55 & 2.53 & 10.61 & 0.00 & 14.14 & 6.06 & 6.06 & 6.57 & 1.52 & 1.52 & 7.58 & 5.56 & 5.05 & 2.53 & 2.02 \\
A. proylei & 7.07 & 0.00 & 3.54 & 1.01 & 8.08 & 8.55 & 2.53 & 11.11 & 0.00 & 14.14 & 6.06 & 6.06 & 6.57 & 1.52 & 1.52 & 7.58 & 5.56 & 4.55 & 2.53 & 2.02 \\
A. roylii & 7.07 & 0.00 & 3.54 & 1.01 & 8.08 & 8.55 & 2.53 & 11.11 & 0.00 & 14.14 & 6.06 & 6.06 & 6.57 & 1.52 & 1.52 & 7.58 & 5.56 & 4.55 & 2.53 & 2.02 \\
B. mori & 6.57 & 0.00 & 4.50 & 1.01 & 7.07 & 7.58 & 2.53 & 10.61 & 0.00 & 14.14 & 7.07 & 5.56 & 6.57 & 1.52 & 1.52 & 9.09 & 4.55 & 5.05 & 2.53 & 2.53 \\
\hline
\end{tabular}

Note: *The amino acids were dominant.

was asparagine $\left(141^{\text {th }}\right.$ site $)$, glutamine $\left(169^{\text {th }}\right.$ site $)$, and alanine $\left(198^{\text {th }}\right.$ site). The diagnostics amino acid for A. pernyi was asparagine (226 ${ }^{\text {th }}$ sites), while the diagnostics amino acid for B. mori was methionine $\left(107^{\text {th }}\right.$ site), methionine $\left(156^{\text {th }}\right.$ site $)$, methionine $\left(165^{\text {th }}\right.$ site $)$, leucine $\left(170^{\text {th }}\right.$ site $)$, methionine $\left(173^{\text {th }}\right.$ site $)$, leucine $\left(178^{\text {th }}\right.$ site $)$, serine $\left(186^{\text {th }}\right.$ site $)$, aspartic acid $\left(187^{\text {th }}\right.$ site $)$, tyrocine $\left(188^{\text {th }}\right.$ site $)$, serine $\left(189^{\text {th }}\right.$ site), isoleucine $\left(190^{\text {th }}\right.$ site $)$, aspartic acid $\left(211^{\text {th }}\right.$ site $)$, and isoleucine ( $234^{\text {th }}$ site).

The amino acid 107th was diagnostic on genus level (Cricula, Antheraea, and Bombyx). While at the family level (Saturniidae and Bombycidae), there were 12 amino acids, those are diagnostics of $156^{\text {th }}, 165^{\text {th }} 170^{\text {th }}$ $173^{\text {th }}, 178^{\text {th }} 186^{\text {th }} 187^{\text {th }} 188^{\text {th, }} 189^{\text {th }} 190^{\text {th, }} 211^{\text {th }}$, and $234^{\text {th }}$ 
sites. This means that only one amino acid sites that can be used as genus marker, and more than one amino acid that can be used as family marker.

Thus COI amino acids showed a low variation in species and genus level, compared to the family level. A possible explanation for this fact is that the amino acids function in the metabolism is universal, including the COI amino acids. Therefore, not surprising if there are small variation between species or genus. On the other hand, if there are large amino acid variations among species or genus means that there are large variations in metabolism (Lunt et al., 1996).

The difference and percentage of amino acid among species were compared and presented in Table 7. A. assama and $A$. roylii has same amino acid. While another species has varies amino acid.

Table 7 showed that the amino acid differences were 0 up to 16 amino acids. C. trifenestrata and $A$. assama and $A$. roylii have smallest difference in their amino acid, while $B$. mori and $A$. yamamai has the biggest difference in their amino acid. A. assama and $A$. roylii has same amino acid. Logical explanation for this fact is the amino acid variation is a reflection of nucleotide variation, although this variation not showed a positive correlation. That mean amino acid varies because of nucleotide varies that derived from of transverse substitution. No change amino acid because of transition nucleotide substitution. Similar result was reported by Funk et al. (1995) which explained that the rate of nucleotide or amino acid substitution were varied in COI sequence based on each species.

\section{Genetic Distance and Phylogenetic Relationships}

Genetic distances among species were compared by Neighbor-Joining method, Kimura 2-parameter (K2P) model for nucleotide sequence and $\mathrm{p}$-distance model for amino acid sequences (Table 8 ). The Table 8 showed that $C$. trifenestrata has the smallest genetic distance with $A$. mylitta, A. proyley and A. roylii, and A. pernyii, A. assama and last B.mori. This suggests that the smaller of genetic distance means greater than the similarities among species.

Based on genetic distances (Table 8), both of the topology of silkmoth phylogeny based on $595 \mathrm{bp}$ COI is presented in Figure 1 and silkmoth phylogeny based on 189 amino acid COI is presented in Figure 2. C. trifenestrata lied on the same node with Antheraea species i.e: A. mylitta, A. yamamai, A. assama, A. roylii, $A$. pernyi, and $A$. proylei, while $B$. mori lied on the outermost node, as the out of group (Figure 1). This means that Saturniidae was philogenetics monophyletic. C. trifenestrata position was relatively consistent with filogenetic relationships based on nucleotide sequences,

Table 6. The varies amino acid and their sites among species

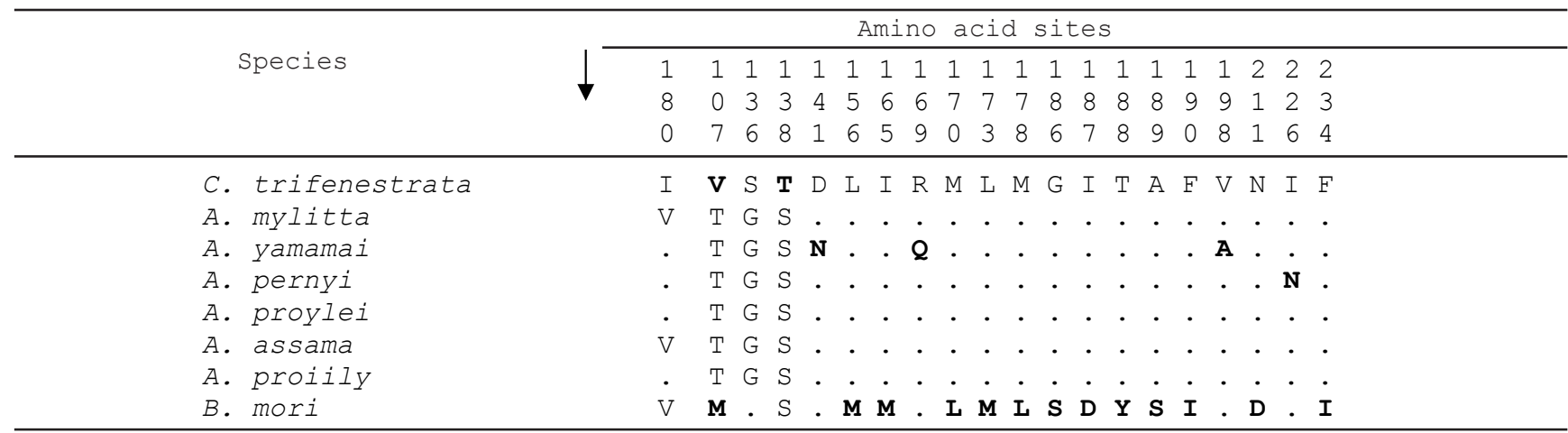

Note: $\mathrm{V}=$ valine, $\mathrm{T}=$ threonine $\mathrm{G}=$ glycine, $\mathrm{S}=$ serine $\mathrm{N}=$ asparagine, $\mathrm{Q}=$ glutamine, $\mathrm{A}=$ alanine, $\mathrm{M}=$ methionine, $\mathrm{L}=$ leucine, $\mathrm{D}=$ aspartic acid, $\mathrm{Y}=$ tyrosine, $\mathrm{I}=$ isoleucine. Bolled letters indicate diagnostic sites for each species.

Table 7. The difference of number and percentage of 189 amino acid sequence on C. trifenestrata compared with GenBank data

\begin{tabular}{|c|c|c|c|c|c|c|c|c|}
\hline Species & 1 & 2 & 3 & 4 & 5 & 6 & 7 & 8 \\
\hline 1 & - & & & & & & & \\
\hline 2 & $5(2,5)$ & & & & & & & \\
\hline 3 & $6(3,0)$ & $5(2,5)$ & & & & & & \\
\hline 4 & $4(2,2)$ & $3(1,5)$ & $4(2,0)$ & & & & & \\
\hline 5 & $3(1,5)$ & $2(1,0)$ & $3(1,5)$ & $1(0,5)$ & & & & \\
\hline 6 & $4(2,0)$ & $1(0,5)$ & $4(2,0)$ & $2(1,0)$ & $1(0,5)$ & & & \\
\hline 7 & $3(1,5)$ & $2(1,0)$ & $3(1,5)$ & $1(0,5)$ & 0 & $1(0,5)$ & & \\
\hline 8 & $13(6,6)$ & $13(6,6)$ & $16(8,0)$ & $14(7,0)$ & $13(6,6)$ & $12(6,0)$ & $13(6,6) 12$ & - \\
\hline
\end{tabular}

Note: $1=$ C. trifenestrata, $2=A$. pernyi, $3=A$. yamamai, $4=A$. mylitta, $5=A$. assama, $6=A$. proylei, $7=A$. roylii, $8=B$. mori . Numbers in parentheses indicate percentage of amino acid difference. 
Table 8. Genetic distances between C. trifenestrata with species from GenBank data, based on 595 bp COI gene at below diagonal and amino acid sequence at above diagonal

\begin{tabular}{cccccccccc}
\hline Species & 1 & 2 & 3 & 4 & 5 & 6 & 7 & 8 \\
\hline 1 & - & 0.019 & 0.019 & 0.019 & 0.025 & 0.025 & 0.031 & 0.082 \\
2 & 0.14 & & 0.000 & 0.000 & 0.006 & 0.006 & 0.013 & 0.082 \\
3 & 0.15 & 0.07 & & 0.000 & 0.006 & 0.006 & 0.013 & 0.082 \\
4 & 0.13 & 0.08 & 0.10 & & 0.006 & 0.006 & 0.013 & 0.082 \\
5 & 0.15 & 0.10 & 0.08 & 0.10 & & 0.000 & 0.006 & 0.075 \\
6 & 0.13 & 0.01 & 0.07 & 0.08 & 0.10 & & 0.006 & 0.075 \\
7 & 0.13 & 0.03 & 0.07 & 0.08 & 0.10 & 0.02 & & 0.082 \\
8 & 0.17 & 0.13 & 0.13 & 0.15 & 0.15 & 0.12 & 0.12 & - \\
\hline
\end{tabular}

Note: $1=$ C. trifenestrata, $2=A$. pernyi, $3=$ A. yamamai, $4=A$. mylitta, $5=A$. assama, $6=A$. proylei, $7=$ A. roylii, $8=B$. mori .

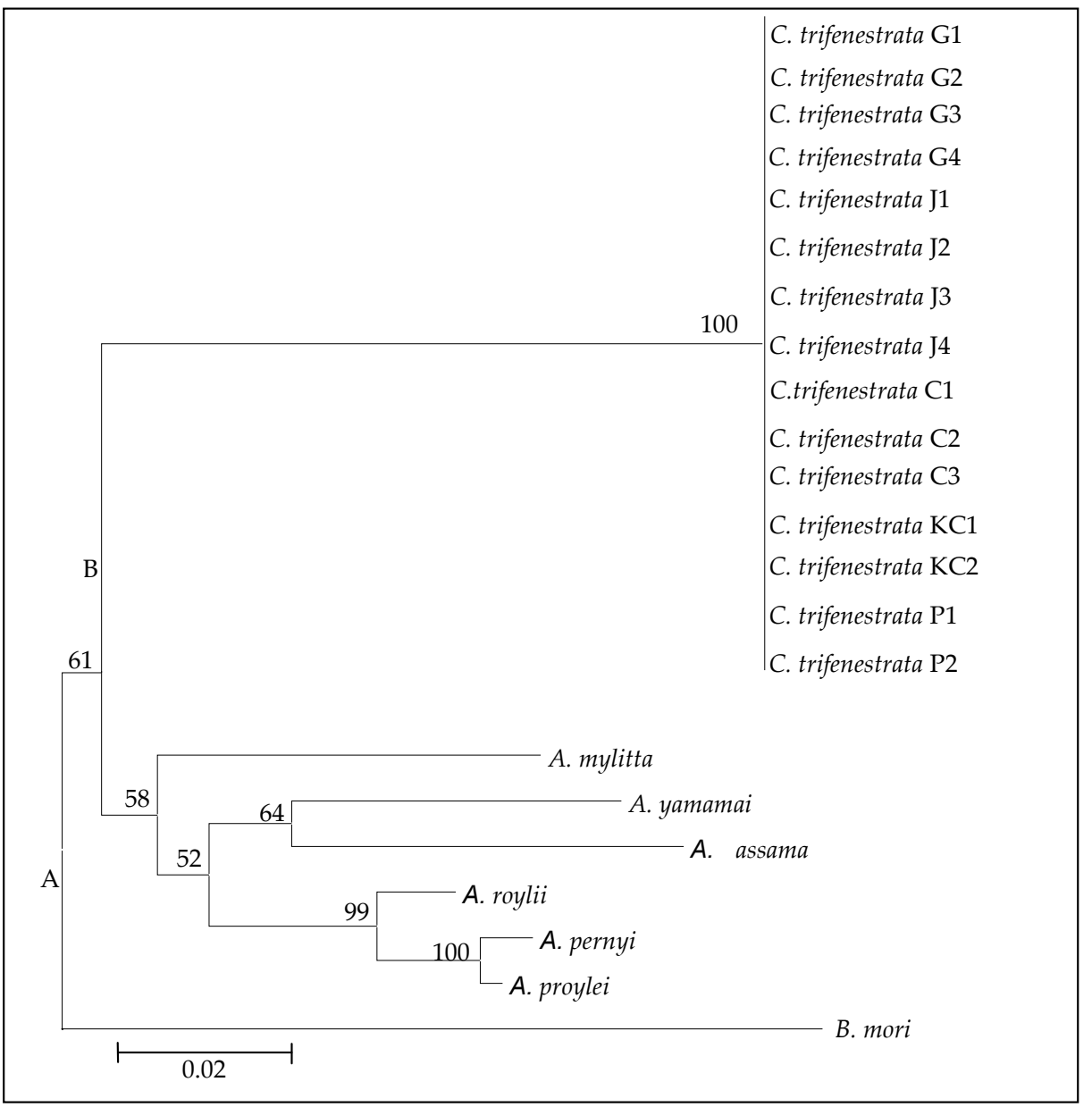

Figure 1. Silkmoth phylogeny based on 595 bp COI with Neighbor-Joining method, 1000x bootstrapped, and Kimura 2-parameter model, node for Bombycidae (A), node for Saturniidae (B).

while $A$. mylitta changed position with A. assama (Figure 2 ). These fenomenom clearly caused of changed amino acid among species that was compared.

The use of different families as outgroup when constructing phylogenies sometimes leads to differences in tree topology (Funk et al., 1995), but this did not occur in C. trifenestrata. Phylogenetic construction using Antheraea as fellow family level (Saturniidae) and B. mori (Bombycidae) as different families did not changed tree topology based on both in nucleotide and amino acid sequence. This means that the phylogenetic signal by COI is still robust. Similar results were also reported by Mahendran et al. (2006) which indicate that the phyilogenetic tree based on COI is more robust than phylogenetic tree based on 16SRNA sequence. 


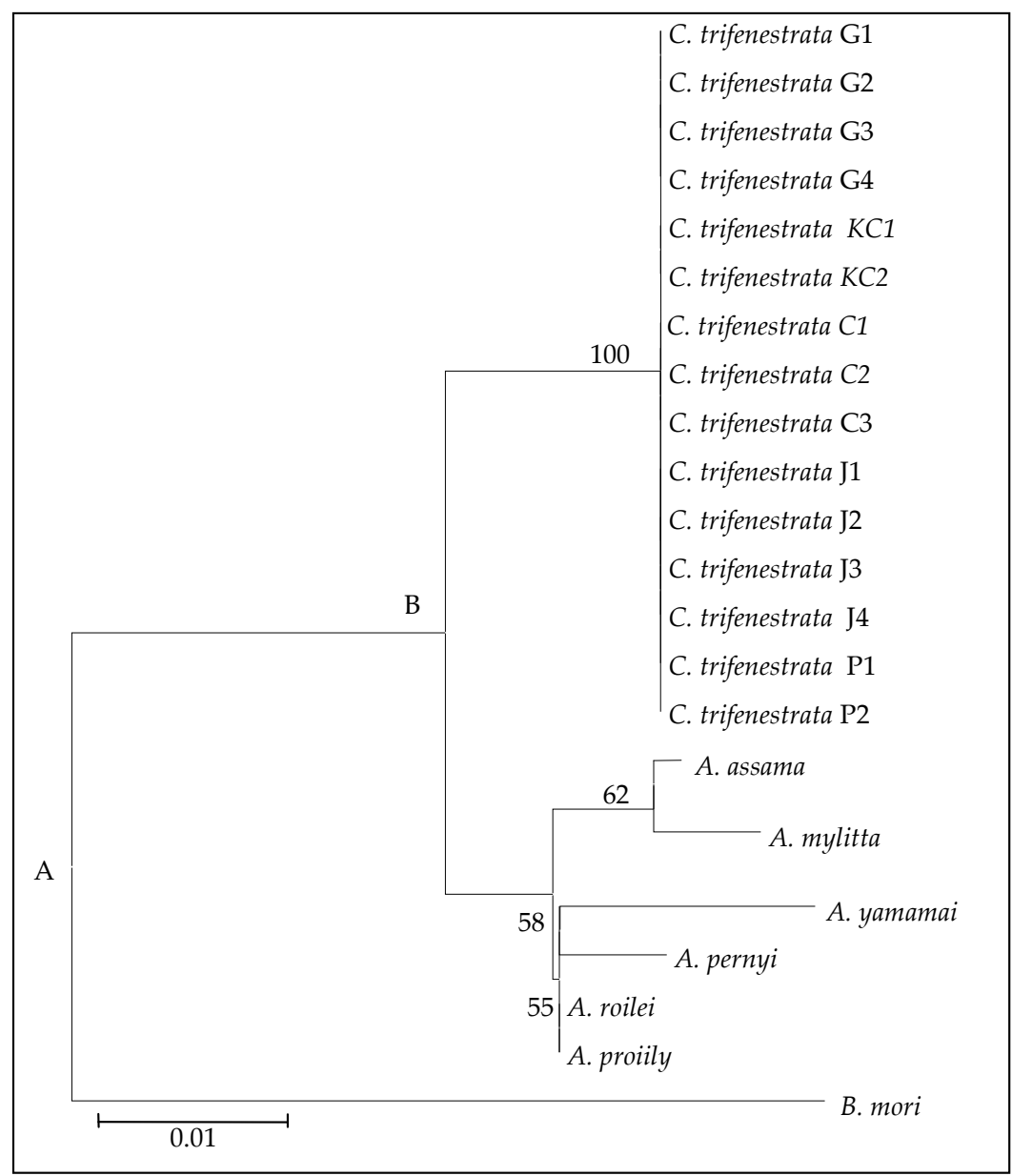

Figure 2. Silkmoth phylogeny based on 189 amino acid COI with Neighbor-Joining method, 1000x bootstrapped, and p-distance model, node for Bombycidae (A), node for Saturniidae (B).

\section{CONCLUSION}

This study successfully characterized the 595 nucleotides of COI gene of $C$. trifenestrata. Nucleotides were dominated by thymine (T) and adenine (A) bases $( \pm 70 \%)$. Nucleotides of 595 bp of COI gene $C$. trifenestratas encoded 189 amino acids. Two amino acids were obtained as species marker for C. trifenestrata, i.e Valine amino acid $107^{\text {th }}$ and threonine amino acids $138^{\text {th }}$. C. trifenestrata lied at the same node with Antherasea spescies, while B. mori was at outhermost node. The family of Saturniidae is monophyletic.

\section{REFERENCES}

Arunkumar, K. P., M. Muralidhar, \& J. Nagaraju. 2006. Molecular phylogeny of silkmoths reveals the origin of domesticated silkmoth, Bombyx mori from Chinese Bombyx mandarina and paternal inheritance of Antheraea proylei mitochondrial DNA. Mol. Phylogenet. Evol. 40: 419-427. http://dx.doi.org/10.1016/j.ympev.2006.02.023 [20 November 2009].

Cywinska, A. C., F. F. Hunter, \& P. D. N. Hebert. 2006. Identifying Canadian mosquito species through DNA barcodes. Med. Veter. Entomol. 20: 413-424. http://dx.doi. org/10.1111/j.1365-2915.2006.00653.x [20 November 2009].
Funk, D. J., D. J. Futuyma, G. Orti, \& A. Meyer. 1995. Mitochondrial DNA sequence and multiple data sets: A phylogenetic study of phyotophagus beetles (Chrysomelidae: Ophraella). Mol. Biol. Evol. 12: 627-640. http://golab.unl. edu/publications/Funketal95.pdf [20 November 2009].

Hulrc, J., S. C. Miller, G. P. S. K. Darrow, D. N. Muller, P. D. N. Hebert, \& G. D. Weiblen. 2007. DNA barcoding confirms polyphagy in a generalist moth, Hontona mermerodes (Lepidoptera: Tortricidae). Mol. Ecol. 7:549-557. http://dx.doi. org/10.1111/j.1471-8286.2007.01786.x

Jiang, S. T., G. Y. Hong, M. Yu, N. Li, Y. Yang, Y. Q. Liu, \& Z. J. Wei. 2009. Characterization of the complete mitochondrial genome of the giant silkworm moth, Eriogyna pyretorum (Lepidoptera: Saturniidae). Int. J. Biol. Sci. 5:351-365. http://dx.doi.org/10.7150/ijbs.5.351 [14 April 2012].

Kakati, L. N. \& B. C. Chutia. 2009. Diversity and ecology of wild sericigenous insect in Nagaland India. J. Trop. Ecol. 50:137-146. www.tropecol.com/pdf/open/.[16 April 2012].

Karimi, J., M. H. Kakhki, \& M. Modarres. 2010. Identifying thrips (Insecta: Thysanoptera) using DNA barcodes. J. Cell Mol. Res. 2: 35-41. http://jm.um.ac.ir/index.php/biology/ article/. [16 April 2012].

Kim, M. J., X. Wan, K. G. Kim., J. S. Hwang, \& J. Kim. 2009. Complete nucleotide sequence and organization of the mitogenome of endangered Eumenis autonoe (Lepidoptera: Nymphalidae). Afr. J. Biotechnol. 9: 735-754 http://www. academicjournals.org/AJB. [5 Oktober 2010]. 
Li, A. L, Q. Zhao, \& Z. Hang. 2005. Molecular phylogeny of the domesticated silkworm, Bombyx mori, based on the sequences of mitochondrial cytochrome $b$ genes. J. Genet. 84:137-142. http://dx.doi.org/10.1007/BF02715839 [5 Oktober 2010].

Li, Y. P., B. Yang, H. Wang, R. Xia, L. Wang, Z. Zhang, L. Qin, \& Y. Liu. 2009. Mitochondrial DNA analysis reveals a low nucleotide diversity of Caligula japonica in China. Afr. J. Biotec. 8:2707-2712. http://www.ajol.info/index.php/ajb/ article/viewFile/60834/49047. [5 Oktober 2010].

Liu, Y., Y. Li, M. Pan, F. Dai, X. Zhu, C. Lu, \& Z. Xiang. 2008. The complete mitochondrial genome of the Chinese oak silkmoth, Antheraea pernyi (Lepidoptera: Saturniidae). Acta. Biochem. Biophys. Sin. 40:693-703. http://dx.doi. org/10.1093/abbs/40.8.693 [5 Oktober 2010].

Liao, F., L. Wang, S. Wu, Y. Li, L. Zhao, G. Huang, C. Niu, Y. Liu, \& M. Li. 2010. The complete mitochondrial genome of the fall webworm, Hypanthria cunea (Lepidopter: Articdae). Int. J. Biol. Sci. 6: 172-186. http://dx.doi.org/10.7150/ ijbs.6.172 [5 Oktober 2010].

Lunt, D. H., D. S. Zhang, D. M. Zhimura, \& G. M. Dewit. 1996. The insect cytochrome oxidase I gene: evolutionary pattern and conserve primer for phylogenetics studies. Insect. Mol. Biol. 5:153-165. http://dx.doi.org/10.1111/j.13652583.1996.tb00049.x

Mahendran, B., S. K. Ghosh, \& S. C. Kundu. 2006. Molecular phylogeny of silk-producing insect based on $16 \mathrm{~S}$ ribosomal RNA and cytochrome oxidase subunit I genes. J. Genet. 85: 31-38. www.ias.ac.in/jgenet/Vol85No1/31.pdf [5 Oktober 2010].

Mueller, R. L. 2006. Evolutionary rates, divergence dates, and the performance of mitochondrial genes in Bayesian phylogenetic analysis. Syst. Biol. 55: 289-300. http://dx.doi. org/10.1080/10635150500541672
Nassig, W. A., R. J. L. Lampe, \& S. Kager. 2006. Checklist of Sumatran Saturniidae. Heterocera Sumatrana. Göttingen: Green Book Series.

Nei, M. \& S. Kumar. 2003. Molecular Evolution and Phylogenetics. Oxford University Press, New York.

Sambrook , J. E. F. Fritsch, \& T. Maniatis. 1989. Molecular Cloning Laboratory Manual. $3^{\text {nd }}$ Ed. Cold Spring Harbour Lab. Press, New York.

Suriana, D. D. Solihin, R. R. Noor, \& A. M. Thohari. 2011. Characterization of partial coding region fibroin gene on wild silkmoth Cricula trifenestrata Helfer (Lepidoptera: Satuniidae). Med. Pet. 34: 23-29. http://dx.doi.org/10.5398/ medpet.2011.34.1.23

Tamura, K., J. Dudley, M. Nei, \& S. Kumar. 2007. MEGA 4: Molecular Evolutionery Genetics Analysis. Software Version 4. Mol. Biol. Evol. 24:1596-1599. http://dx.doi.org/10.1093/ $\mathrm{molbev} / \mathrm{msm} 092$

Toda, S. \& T. Murai. 2006. Phylogenetic analysis based on mitochondrial COI gene sequences in Thripstabaci Lindeman (Thysanoptera: Thripidae) in relation to reproductive forms and geographic distribution. Appl. Entomol. Zool. 42: 309-316. http://dx.doi.org/10.1303/aez.2007.309

Tuskes, P.M., J. P. Tuttle, \& M. M. Collins. 1996. The Wild Silk Moths of North America. Cornell University Press. USA.

Weagner, B., A. Reineke, B. Lohr, \& P. W. Zebit. 2006. Phylogenetic study of Diadegma species (Hymenoptera: Ichneumonidae) inferred from analysis of mitochondrial and nuclear DNA sequence. Biol. Control. 37: 131-140. http:// dx.doi.org/10.1016/j.biocontrol.2006.01.004

Wilson, J. J. 2010. Assessing the value of DNA barcodes and other priority gene regions for molecular phylogenetics of Lepidoptera. Plos One 5: e10525. http://dx.doi.org/10.1371/ journal.pone.0010525 [14 April 2012]. 